\title{
MIKKJEL FøNHUS OG DYRESKILDRINGEN
}

\author{
HENNING HOWLID WARP
}

\begin{abstract}
Mikkjel Fønhus and the Portrayal of Animals

In his novels, from his debut in 1917 and unto his last novel in 1973, the Norwegian author Mikkjel Fønhus writes about what is in the periphery of our attention: the wilderness and the wild animals. Technology has done that a direct contact with nature is no longer necessary for us: what we relate to is more and more social and cultural practices. Fønhus investigates non-human perception and shows us how we share, or should share, the landscape with non-domestic animals.
\end{abstract}

Keywords: Mikkjel Fønhus; Norwegian literature; wilderness; wild animals; animal studies

\section{Innledning}

I boka Survival. A Thematic Guide to Canadian Literature risser Margaret Atwood opp tre ulike måter å skrive om ville dyr på i skjønnlitteraturen. I den britiske tradisjonen med Kiplings Mowgli-historier, Beatrix Potters barnebøker om Peter Rabbit, Lewis Carrols Alice in Wonderland m.fl. - er dyr antropomorfisert, skriver Atwood: De snakker flytende engelsk og er plassert inn i en hierarkisk sosial orden som ligner det britiske samfunnet. I den amerikanske tradisjonen kan dyrene ikke snakke, og de har ikke klær, men de er sjelden i sentrum for fortellingen. Dyrene opptrer i jakthistorier der jegeren søker å vinne over naturen, men også å overta noe av styrken og vitaliteten til dyret de skyter. De amerikanske dyrehistoriene er i sitt vesen imperialistiske, mener Atwood. Mot dette setter hun de canadiske dyrefortellingene som er fortalt eller sett fra dyrets ståsted og dyrets endelikt ofte er tragisk, på grunn av jegeren, men også på grunn av kampen mot andre dyr. I disse historiene er det lagt opp til at vi skal sympatisere med dyrene, ikke med jegeren. Atwood oppsummerer de tre tradisjonene slik: «English animal stories are about 'social relations', American ones are about people killing animals; Canadian ones are about animals being killed, as felt emotionally from inside the fur and feathers» (Atwood 74).

Hvordan fremstillingen av ville dyr i norsk litteratur generelt er, er et for stort spørsmål for en artikkel, men jeg skal her ta for meg én forfatter, Mikkjel Fønhus (1894-1973), 
som på interessant vis kan sies å forene den amerikanske og den canadiske tradisjonen: Vi følger både jegeren og dyret, og det på en måte som utfordrer oss i hvor sympatien skal ligge.

Hvis man blar opp på en tilfeldig side i en roman av Mikkjel Fønhus og begynner å lese om at hun eller han tenker det ene eller det andre, lengter etter eller frykter noe, er det ikke sikkert at det er et menneske vi er inne i hodet på. Det kan være et dyr sitt perspektiv vi følger - en bjørn, en jerv, en gaupe; en hønsehauk, en hubro, ei kråke. Flere av boktitlene viser dette dyrefokuset i forfatterskapet: Troll-Elgen (1921), Reinsbukken på Jotunfiell (1926), Skogens eventyrer; fortellingen om en rev (1929), Varg (1933), Beveren bygger ved Svartkjenn (1937), Tredalsmåren (1950), Jerv (1959), Gaupe (1966), Hubroen roper (1971), Villmarksoteren (1972) m.fl. Det er ikke rene dyrefortellinger det er snakk om, slik vi kan finne i bøker for små barn, der antropomorfiseringen av dyret er total, med den følge at innlevelse og identifikasjon blir lesemodus - som i den britiske tradisjonen, slik Atwood utlegger den. Fønhus kan som forteller følge dyret lenge, men vil før eller siden bringe mennesker inn i landskapet, for så å skifte perspektiv mellom dyr og menneske. Ofte kan romanen avsluttes fra dyrets synsvinkel, mennesket er ikke nødvendigvis det privilegerte sansesentrum.

Typisk for Fønhus er at menneskene fremstilles som å dele et landskap med dyrene. Fortellingen går fram og tilbake mellom menneskeverden og dyreverden og viser hvordan menneske og dyr opplever den samme naturen på ulik måte. Grensen mellom livsverdenene er likevel porøs. Det er sjelden en idyllisk sameksistens mellom mennesker og ville dyr vi møter, heller en kamp der en ugle plutselig kan ta katten på gården, en bjørn kan slå ihjel hesten eller ta en sau i utmarka. Mennesket selv frykter både bjørn og ulv, mens dyrene på sin side blir jaktet på av menneskene. Innad i dyreverden er det også en stadig kamp, spise og bli spist: en ulv innhenter et reinsdyr, en mår tar et ekorn, en hubro setter klørne i en tiur, en rev sniker seg innpå en orrhane i snøen. Selv om naturen ikke tegnes som et harmonisk hele i betydningen idyll, er det et hele på den måten at livet stadig går videre, selv om enkeltindividet bukker under. Det er ingen religiøs overbygning over dette, selv om kirken i noen fortellinger er til stede i landskapet. Som Rolf Brandrud viser i biografien Drømmejegeren hentet Fønhus i sine dyreskildringer inspirasjon fra Jack London og hans darwinistisk pregede fortolkning av kampen for tilværelsen (Brandrud 51). I bøkene skildrer Fønhus dyrelivet som en hard kamp med mange tapere; ofte ender det dårlig for det dyret vi lesere har blitt kjent med og gradvis sympatisert med, som i Reinsbukken på Jotunfiell (1926) der det hvite reinsdyret gjennom tolv år har klart å unnslippe både jeger og jerv, til leserens tilfredshet, før reinsbukken en dag faller ned i en bresprekk og dør. Dette skildres usentimentalt og konstaterende, som en aksept av naturens farer.

Ingen andre norske skjønnlitterære forfattere vier så mye oppmerksomhet til ville dyr som Fønhus. Mens det hos andre kan være innslag av dyreskildringer, eller korte møter mellom menneske og dyr i naturen, går Fønhus dypere ned i forståelsen av dyrelivet ved å følge et enkeltdyr over lengre tid. Hvordan denne dyreskildringen arter seg er det jeg vil undersøke i denne artikkelen, i tillegg til møter mellom mennesker og dyr. I et foredrag om dyr i 1922 sier Fønhus: «[...] dyra er våre kamerater og medarbeidarar her på den planeten som heito Jorde, og sjølv om dyrets kjensleliv e enkelt, so e det der, og me plikta ta hensyn til det» (Brandrud 82). 
Jeg vil i det følgende se nærmere på fire bøker der dyr er hovedperson: brunbjørn (Der villmarka suser, 1919); hauk (Det skriker fra Kverrvilljuvet, 1920); jerv (Jerv, 1959) og grågås (Villgås flyr mot nord, 1968). Avslutningsvis vil jeg si noe generelt om dyreskildringen hos Fønhus, blant annet med eksempler fra Trollelgen (1921), en av Fønhus' mest populære bøker. Men først en kort presentasjon av forfatterskapet, og en forskningshistorikk.

\section{Forfatterskapet}

Mikkjel Fønhus var født i 1894 i Sør-Aurdal i Valdres. Han vokste opp i annen etasje på Lundby landhandel, som moren drev, faren hadde dødd da Mikkjel var to år gammel. Etter middelskole i Aurdal tok han artium i Kristiania i 1913, begynte på jusstudiene, men avbrøyt og jobbet en tid som journalist i Norske Intelligenssedler, før han flyttet hjem til Valdres for godt, der han klarte å livnære seg av forfatterskapet. Fra debuten i 1917, 23 år gammel, og fram til 1973 ga han ut 39 prosabøker (romaner og fortellinger) og 2 skuespill. Posthumt kom det ut flere romaner. Ifølge Fønhus' biograf Rolf Brandrud hadde bøkene pr. 1993 solgt i 1, 9 millioner eksemplarer (Brandrud 216). Fønhus fikk i 1952 Statens kunstnerlønn på livstid. Han døde i 1973, 79 år gammel.

Fønhus' debutroman Skoggangsmann (1917) kom ut samme år som Knut Hamsuns Markens grøde og et år før Gabriel Scotts Kilden, eller brevet om fiskeren Markus (1918). Alle tre romaner har sterke individualister som hovedpersoner, menn som lever tett på naturen, fjernt fra byen og det moderne liv. Mens Hamsun har bonden og Scott har fiskeren som hovedperson, er det en jeger og etter hvert en fredløs som er hovedperson hos Fønhus. Alle tre romaner skaper alternativer til det moderne liv. Mens Isak hos Hamsun og Markus hos Scott er positive skikkelser, er Hans Trefothaugen hos Fønhus en mer problematisk karakter, som ender sitt liv i fengsel. Likevel målbærer også han gjennom sitt liv i naturen en sivilisasjonskritikk; han er aldri så lykkelig som når han ligger på en fersk granbarseng innpå skogen og forer bålvarmen med furu som han har hogd på stedet. Mens naturen i Markens grøde skildres som «vennlig» - for eksempel hører vi ikke om rovdyr, og Isak går ikke på jakt - er det hos Fønhus villheten i naturen som utforskes og beskrives, både villheten i landskapet, i dyrelivet og i menneskelivet. Villmarksnaturen blir i bøkene som en del av menneskenaturen, på godt og vondt. At de store skogene og fjellet er natur vi ikke skal underlegge oss og kontrollere, men være brukere av og forholde oss respektfulle til, kan sies å være en underliggende norm i romanene.

De fleste av Mikkjel Fønhus sine bøker utspiller seg i de traktene der han bodde, i Valdres, med Hallingdal i vest og Gudbrandsdalen i øst. Han har imidlertid også skrevet bøker fra Nord-Norge, blant annet om samene og reinsgjeting, som i Mannen og hunden på den store vidda (1955). I slike fortellinger er gjerne en person fra byen bindeledd for leseren, som i Varg (1933) der en adjunkt sørfra ønsker å lære om reindriftssamenes liv og slår seg ned hos dem for en periode. Noen av romanene skildrer et yrke: tømmerhogger i bøkene Ontarioskogen: skildringer fra nordmenns skogsarbeiderliv i Canada (1934) og Urskogene. Fortellinger fra Canadas villmark (1964), og tømmerføter i boka Tømmerfløterne (1952). I disse blir vi kjent med arbeidere i primærnæringene. Det samme gjelder bøkene fra Svalbard, om fangstmannsliv og gruvedrift: Under Polarlyset (1922), Vandringen mot nord (1927) og Menn under nordlyset (1948). 
Noen av romanene har et kulturformidlende perspektiv, som Køia $i$ Tusterdalen (1945) og Kampen mot villmarka (1946), om utvandrere fra Gudbrandsdalen som på begynnelsen av 1800-tallet drar til Nord-Norge for å rydde seg gård. I Det raser i Haukefjellet (1965) tar Fønhus utgangspunkt i steinrasene i Loenvannet i Stryn i 1905 og 1936, der mange mennesker omkom.

Et møte er ofte av konfronterende eller voldelig karakter i Fønhus' bøker, enten det er dyr i mellom, mennesker i mellom eller mennesket i møte med ville dyr. Ofte ender det dårlig, enten for dyret vi har fulgt gjennom fortellingen, eller for mennesket. I Gullgraverne på Finnmarksvidda (1962) får vi høre om eventyreren Torger Melleset som har reist fra Oslo til Finnmark for å vaske gull i elvene. Han blir ranet og drept av en finlender som også er gullvasker, og forbrytelsen blir aldri oppklart. I Mannen med ormeøynene (1951) er det nordmenn som er overgripere mot finlendere i Hedmark, i grensetraktene mot Sverige: En finsk gård blir brent ned fordi nordmennene mener mannen på gården, Karvas-Heikki, tar for mye av viltet i skogene. Hans kone og barn dør og de skyldige blir aldri straffet.

Det er oftere konflikt enn fredelig sameksistens mellom folkegrupper hos Fønhus, i møtet mellom nordmenn, finner og samer. Mellom bygdelag er det også gjerne strid, som i romanen I hine hårde dage (1960), som skildrer en krangel mellom folk i Valdres og Gudbrandsdalen om bruksrettighet av fjell og vann, om hvor skillet går. Både rettssaker og selvtekt tas i bruk i boka som delvis bygger på historiske forelegg. I Raudalsdansen (1924) går striden ikke østover til Gudbrandsdalen, men vestover til Hallingdal: På et årlig dansestevne utspiller det seg et blodig sjalusidrama mellom menn fra de to dalførene.

Rundt halvparten av bøkene til Fønhus er det vi kan kalle folkelivsskildringer og kulturhistoriske romaner. Disse har begrenset interesse i dag, blant annet fordi Fønhus sine personskildringer er ganske grunne. Det er de andre ca. tjue bøkene med dyreskildringer som er hans viktigste bidrag til norsk litteratur. De er de mest estetisk sterke, men også de i dag mest relevante, på grunn av sitt fokus på naturvern, sin implisitte sivilisasjonskritikk og dyrepsykologiske dybde: Fortellingene former et felleskap med dyrene, får oss til å se at vi er i verden sammen med dem.

\section{Forskningshistorikk}

Omtalen av Mikkjel Fønhus sitt forfatterskap i norske litteraturhistorier har gradvis minsket i omfang for til slutt å forsvinne helt. I 1955 viet Philip Houm fire sider til Fønhus i bind seks av verket Norges litteratur: Forfatterskapet brakte et «mektig» og «nytt stoff» inn i norsk litteratur, «med en språklig kraft og en skildrende evne langt ut over det vanlige» (Houm 274). Tjue år etter, i 1975, er presentasjonen av Fønhus begrenset til under én bokside, i femte bind av Norges litteraturhistorie, skrevet av Kjølv Egeland. Forfatterskapet omtales fortsatt rosende, med karakteristikker som «djervt medrivende» og «fargerikt og romantisk-spennende» (Egeland 292). I Harald og Edvard Beyers Norsk litteraturhistorie (1978) er det bare tre setninger om Fønhus, men igjen av positiv karakter: «Ingen har skrevet bedre om dyr og jegerliv enn han, og han har en troverdig evne til å se tingene under dyrenes synsvinkel»(Beyer 364). Willy Dahl, i Norges litteratur, fra 1984, har kun én setning om Fønhus: «Debuterte med romanen Skoggangsmand i 1917, skrev siden ca. 50 bøker med motiv fra norsk skog- og villmarksliv, de beste av dem 
gjerne i 'dyreperspektiv'»(Dahl 394). Og med det er det slutt, i Norsk litteratur i tusen år, ved Bjarne Fidjestøl m.fl., er Fønhus i 1996 helt utelatt. I Per Thomas Andersens Norsk litteraturhistorie, fra 2012, som i dag er pensumverket for litteraturstudenter, er Fønhus heller ikke omtalt. Betyr det at forfatterskapet ikke lenger er relevant? Denne artikkelen utfordrer en slik mulig slutning, i tillegg til å være et bidrag til en litteraturvitenskapelig utforskning av forfatterskapet. Pr. i dag fins det nemlig ingen litteraturvitenskapelige artikler om det.

Interessen for Fønhus kommer imidlertid til syne på andre måter, blant annet gjennom at det er skrevet hele fire biografier om ham: Ulf Gleditsch: Mikkjel Fønhus. Skoggangsmann og tradisjonsbevarer (1960), Torbjørn Børte: Mikkjel Fønhus - fra Nissebakken til Thika River (1972), Gudbjørg Fønhus Stensrud: Mikkjel - far min (1985) og Rolf Brandrud: Drømmejegeren. En biografi om Mikkjel Fønhus (1993). Gleditsch skriver i forordet til sin biografi at boka «er ingen litterær analyse, men et forsøk på å tegne et portrett av mennesket Mikkjel Fønhus» (Gleditsch 1960: 7). Torbjørn Børtes bok bygger på intervjuer med forfatteren. Begge biografiene er skrevet mens Fønhus levde og har ikke noe kritisk perspektiv på forfatterskapet. Det har heller ikke Gudbjørg Fønhus Stensruds bok, som langt på vei er en minnebok om faren. Rolf Brandruds biografi gir imidlertid fortolkninger og kulturhistorisk plassering av verkene, i tillegg til å drøfte Fønhus' ideologiske og politiske syn. I 1974 ga Valdres Historielag ut Mikkjel Fønhus. Slik som vi husker ham, der flere norske forfattere skriver om Fønhus: Johan Borgen, Halldis Moren Vesaas, Ebba Haslund, Nils Johan Rud, Kåre Holt m.fl. I Norske forfattere på norsk forlag. Aschehoug-bøker i tiden rundt 1905, skriver Ivar Havnevik om de første bøkene til Fønhus, med fokus på Der villmarka suser (1919).

I 2018 utfordret Nasjonalbiblioteket forfatteren Tore Renberg til å nylese Fønhus, i foredragsserien «Fortidas folkelesnad». Foredraget kom høsten 2018 ut som et hefte med tittel Tore Renberg les Mikkjel Fønhus. Renberg er fascinert av dyreskildringene til Fønhus, naturbeskrivelser som springer ut av kunnskap, entusiasme og formidlingskraft. Etter endt lesing føler han at han har lært noe om det dyret som var hovedperson i fortellingen, og lært noe om samspillet i naturen (Renberg 62). Renberg diskuterer også begrensningene i forfatterskapet, at Fønhus er plottsvak og dramaturgisk enkel, og ofte ikke makter å holde på én tråd, men stadig introduserer spennende dyr og folk, for så å slippe dem. «[...] han har ei manglande evne til å avslutta tekstane sine» (62).

At fortellingene til Fønhus ofte har en episodisk framfor en episk framdrift, har vært påpekt av flere, blant annet av Helge Krogh i 1926. Dette er imidlertid for Krogh - og for Renberg senere - en svakhet som ikke desavuerer forfatterskapet: «Mikkjel Fønhus' skildrende, malende evne er fenomenal; og det er skildringene mer enn selve beretningen, som gir hans siste bok verdi [...] Han kan i nogen få, korte setninger oprulle et mektig landskap, i linjer, i farver, i lys og skygge» (Brandrud 119).

\section{Bjørn. - Der villmarka suser (1919)}

Fønhus sin andre bokutgivelse, Der villmarka suser (1919), består av to frittstående fortellinger av omtrent samme lengde: «En villmarkssønn» og «Fortellingen om slagbjørnen Rugg». Det er med denne siste at Fønhus for alvor etablerer seg som en dyreskil- 
drer. Fortellingen åpner slik: «Dette var en aprilnatt i Hedals-Vassfaret, en natt med tynn hoggeskare og sus fra skog» (3). ${ }^{1}$ Deretter kommer en besjeling av landskapet: «Mellom kalkhvite fjell krøkte Vassfaret nordover. [...] Langt nordi lå en foss vaken» (3). Så introduseres dyrelivet: «Storfuglen sov på nattkvisten, en søvn på vekten mellom liv og død; for reven var svolten, og måren var svolten, og hubroen seilte som en lydløs skugge over skogen» (4). En hare sitter på myra, fortsatt vinterhvit i pelsen, men med brune flekker som viser at våren nærmer seg. I neste øyeblikk er den tatt av hubroen; klørne til fuglen har punktert lungene. En mår klatrer lydløst oppover en trestamme og angriper en tiur, en rev tar en orrhane. "Mange dyr mistet livet i natt» (4). I neste scene skildres ei binne som kommer ut av hiet med en unge: «Da solflommen hadde sunket en stund denne aprilmorgenen, stakk et bjønnehode ut av ura» (5). Ungens første møte med verden blir levende skildret, og de to bjørnenes vandring etter mat.

Først på dette tidspunktet bringes et menneske inn i handlingen: «Samme kvelden arbeidde to hedølinger seg nordover Vassfaret» (7). De ser spor etter bjørn og bestemmer seg for å legge ut sin egen døde hest som åte. En bjørnesaks settes opp, binna går i den, mens ungen kommer seg unna. Om bjørnungen heter det: «Når han gikk, var det slik ruggende rytme i gangen, derfor skal han hete Rugg» (10). Med det er hovedpersonen i fortellingen etablert.

Etter et tidshopp på fem år møter vi Rugg igjen:

Sia den våren mor hans ble skutt, hadde han fem vintrer ligget i hi, én vinter på busu og fire under trerot. [...] Uro visste han ikke hva var. Livet hans fløt lik en doven strøm; men han holdt seg borte fra menneskene og alt deres. Han åt når han var svolten og sov når han hadde trang. Livet var bare en stadig gang i fjella etter mat, timelang døsing på solrabbene, og dette var nok til å gi tilværet innhold for Rugg. (19)

Det som en dag forstyrrer denne likevekten, er en saueflokk som trenger seg opp mot ham. Han hører den metalliske lyden av bjeller: «[...] det sildret så ekkelt i ørene, og den ødela freden omkring ham. Fjellet skulle være stilt» (20). Bjørnen angriper sauen, og kjenner han liker smaken av blod. Fra nå av blir han slagbjørn, i menneskenes øyne.

Det er lagt opp til at leseren skal sympatisere med Rugg; det at sauer har trengt inn i hans område, er ikke hans skyld. Bebyggelsen sees fra ute i landskapet, på avstand: «Et djupt og breitt dalføre grov seg gjennom jorda beint under ham. Mot aust traff det sammen med et annet dalføre, og der kunne han se noen kvite prikker som lyste i sola. Det var husene der menneskene bodde» (37). Bjørnen har ikke noe ønske om å gå dit:

Rugg ville attende til Vassfaret. Han lengtet dit [...] Ingensteds var det som i Vassfarfjella. Der var vidder, der var fred. Ingensteds blånte og rødnet bærrabbene slik som i Vassfarfjella. Ingensteds var det så mange spor etter elgsdyr som der... (36)

Nå inntreffer en hendelse som leseren skjønner vil ende bjørnens liv, selv om det er utløst av tilfeldigheter. «Så var det den sommeren da han drepte en liten lyshåret gutt på hallingfjellet», heter det, konstaterende mer enn dramatiserende (48). Gutten er ute og leter etter en bjellesau og går rett på Rugg, som blir overrasket der han ligger og hviler. Bjørnen

1 Alle sitater fra Fønhus sine bøker referer til Samlede verker-utgaven, Aschehoug 1976. 
angriper og gutten dør. Selv i en forståelse av at konflikten menneske-bjørn er menneskeskapt, godtar vi at bjørnen blir skutt, selv om vi også beholder Ruggs perspektiv. Fønhus lykkes her i å skape en dobbel leseridentifikasjon, vi følger både dyret og mennesket.

\section{Hauk. - Det skriker fra Kverrvilljuvet (1920)}

I Fønhus sin tredje roman, Det skriker fra Kverrvilljuvet (1920), er hovedpersonene et haukepar og ungene deres. Vi får høre om et kraftig vindvær som skaper uro i skogen: «Det er ikke rolig i skogen i natt, ikke i lufta og ikke på marka» (32). I kontrast til dette skildres reirlivet som et trygt hjem: «I haukereiret ligger hunnen, med vingene breidde. Under seg kjenner hun ungene som en bløt, varm pute [...]» (33). Det er et bilde av ro og harmoni. Den innledende naturbeskrivelsen har imidlertid varslet om at noe uhyggelig vil skje. Det viser seg å være et angrep av en mår som kryper forsiktig rundt på greinene og leter etter ekorn eller fugleunger. «Det er døden selv som går gjennom skogen i natt [...]» (34). Hauken, som ellers er høyt oppe i næringskjeden, er nå plutselig i en sårbar posisjon. Måren angriper og en kamp starter i grantreet. Måren freser og biter, hauken slår med de krumme klørne og hugger med nebbet. I striden faller begge ned mot jorda, dødelig såret. Måren kryper inn mellom to mosegrodde kjempesteiner der den kruller seg i hop og dør, på samme sted der den ble født, mens hauken flyr opp i redet, med tarmene hengende ut. Der dør den, over ungene sine.

Hannhauken kommer etter en stund tilbake med en orrhøne som ungene river opp og spiser. «Den ene av dem, en med en liten lys flekk over høyre øyet, var grådigst. Han skubbet de andre to til side [...]» (41). Det gjøres så et hopp en uke fram i tid. Den døde hunnhauken er sparket ut av redet og ungene har vokst og er nesten like store som foreldrene. Men fortsatt kan de ikke fly. Hannhauken strever det han kan for å holde liv i ungene. Da begynner andre akt i tragedien. En haukefanger, Eivind Romset, har murt opp en steinvarde på en høy, stupbratt fjellkamp der han har spent opp en stålsaks for å fange ørn som ofte lander på varder. Det blir imidlertid hannhauken som setter seg her, saksa går igjen og den blir drept.

Tredje akt i dramaet utspiller seg i haukereiret der ungene venter på mat. «Hele den dagen og hele den neste med. Da tok de til å svelte» (47). Ungene var vant til å vente, heter det, men den tredje dagen begynner sulten å pine dem. Nå begynner en nådeløs nedtelling mot døden, samtidig som antall dager uten mat øker. Alle fjær- og kjøttrester som lå på reiret er snart slukt. «Så dukker dagen inn i en dunkel natt. Den er borte noen timer, kommer så fram igjen som reinvasket, stadig med sol. Dette er den fjerde» (48). En og annen maur kryper over reiret uten at ungene legger merke til det, de blir mer og mer apatiske. Så skjer det noe som får livslysten til å brenne i dem igjen: En jaktfalk kommer seilende over juvet og skriker, og de tror at det er hannhauken. «Og de svarer skjærende alle sammen, et svar i jubel, fra barn som venter svoltne på mat. - Pi-i-i!» (49). Men falken forsvinner. «Og det blir en kveld til, en natt til, og en dag til. Det er den femte» (49). Ungene har hakket i granleggen, de har hakket i tørrkvisten, men det gir ikke mat. «Sjette dagen blir det regnvær» (50). Det gir en liten lise, de får i seg litt vann, men de blir også våte og kryper tett sammen for å få kroppsvarme fra hverandre. Regnet fortsetter. «Slik ligger de. Tre skogens barn, som har gitt livet opp» (52). Et ekorn kommer klatrende og 
nærmer seg, han ser etter et småfuglreir å rane. «Den ene ungen, han med den vesle grå flekken over øyet, vakner ved at det krafser noe etsteds over ham» (52). Hauk-ungen hogger ut etter ekornet, men vingene vil ikke bære ham. Ekornet trekker seg tilbake og forsvinner. «Så kommer kvelden i dag også. Det er nå seks dager sia Hannhauken gikk i saksa til Eivind Romset» (53). Et lynnedslag får ungen med flekk over øyet til å reise seg i reiret. Han ser på de to andre som ligger der som en fjærdynge. Så hogger han nebbet og klørne i en av søsknene sine. Om offeret får vi høre: «Stakkaren får ikke engang reist seg. Han er så inderlig slapp og utpint at han orker ikke» (54).

De to gjenværende ungene spiser den tredje, nå har de fått mat i seg til å leve litt lenger. Tre dager etter de har drept broren sin, og snaupillet knoklene av ham til det ikke er mer å pille igjen, sparker de ham ut av reiret. Fortellingen er så fremme ved den ellevte dagen etter hannhauken døde. En kattugle kommer flyvende og angriper, men blir slått tilbake av haukungene. «Og dagen ebber ut. Nå står det bare én levende på reiret. Han står og hakker i seg kjøttet av sin egen bror» (58). Av de fem haukene, hann, hun og tre unger, er det bare én igjen. Hans tid er imidlertid også snart ute. Fortelleren viser oss hvordan spyfluene fråtser i haukemora under grantreet, og at tanngardene til den døde måren griner i det svake dagslyset som så vidt når inn mellom steinene til der den ligger. Haukungen i reiret orker ikke reise seg mer; vingene skjelver, roer seg, den gule ringen om pupillene svartner av, og så er han død. Fortellingen slutter med at en trane flyr med lange, sørgmodige skrik over Kverrvilljuvet. Tragedien er kommet til sin ende.

Uten haukefangeren Eivind Romset ville de tre ungene ikke ha sultet ihjel i reiret. Det ligger likevel ikke noen kritikk av hans virksomhet i fortellingen; dette er fra en tid saksefangst var lov og det var skuddpremie på hauk. Romset lever i skogstraktene og høster av det som er der. Likevel blir dette fjernt fra en jaktfortelling der jegeren triumferer med sitt bytte. Ved at perspektivet skifter mellom jeger og dyr, og perspektivet i langt større deler av fortellingen er hos haukene enn hos mennesket, blir Det skriker fra Kverrvilljuvet en fortelling som gir oss utvidet forståelse av dyrelivet i skogen. Etter å ha lest Fønhus' fortelling vil man ha et mer nyansert syn på hønsehauk enn bare som en farlig rovfugl.

\section{Jerv. Fortellingen om Treføtingsjerven og Heine Juvet (1959)}

En strategi i å forstå rovdyret ved stadige synsvinkelskift finner vi også i Fønhus’ roman Jerv. Fortellingen om Treføtingsjerven og Heine Juvet (1959). Handlingen er fra fjellvidda i det sørlige Norge på grensen til Vestlandet. En samefamilie har ført tamrein sørover fra Børgefjell og lever av å gjete dem for eieren. Samen, Bengt, ser en dag to jerver, som han prøver å drepe med stein, siden jerven tar reinsdyr. Han lykkes ikke, men forteller om jerven til en mann han treffer, Heine Juvet, som har en gård beliggende på en fjellkant fem hundre meter over fjorden. Han er ofte inne på vidda på jakt, blant annet på ryper, som han fanger i snarer. Nå vil han jakte på jerven. «Og Heine kjente seg sjøl som litt av en jerv, en fri og rekende fant i vide fjell. Slik likte han det. Ikke høvde det for Heine Juvet å tasse i lengere tid som en buhund heime på garden» (37). Vi følger vekselvis Heine og en av jervene. Det er ikke bare mennesket som skildres når det gjelder væremåte og lynne, men også jerven. Dens natur er å streife, ensom, alltid på vandring, «som besatt 
av fredløshet», heter det (17). Jervens måte å bevege seg på skildres som å gå på breie og store labber, litt skrevende, gjøre kroker, men holde retningen: «Han vandret i fjellet på sin slekts egen måte: når han kom til en litt større stein, da kunne han hoppe oppå den, stå der og se seg omkring, prøve værdraget med nesen [...]» (11). Teksten gir inntrykk av å mime jervens forestillingsverden når en hund oppleves som «en bjeffende rev», og menneskehender beskrives som «labber som det ikke fantes hår på» $(10,64)$.

Jerven er i sitt rette element oppe i høyfjellet vinterstid. Det er imidlertid også Heine Juvet: Han drar med seg en kjelke som han kan overnatte på ved å spenne opp vadmel over som et telt, og han har en skinnfell til å ligge på: «Bare månelyset rådde over nattelegeret til fjellkaren som sov, sov trygt der midt i en veldig, tilsnødd, isnende øydemark» (18). Jerven stjeler ved et tilfelle ryper fra snarene til Heine. Det vil si, tyveriet er fra et menneskes perspektiv, jerven vet ikke at disse rypene alt er fanget, noe vi forstår ut fra dens opplevelse av snarene og fangsten: «[...] ene beinet på rypa satt fast i noe som hadde snørt seg omkring det, et grant, rødaktig strå liksom, og dette strået var festet til en bjørkekvist» (19). For Heine er det imidlertid klart at dette er hans ryper, og han setter ut to store sakser for å fange jerven. Jerven går i saksa med den ene foten og blir sittende fast, men innen Heine to dager etter er tilbake ved fellene, har dyret gnagd av seg foten og rømt. Etter dette blir han kalt Treføtningen. Samtidig som vi lever oss inn i jervens lidelse, skjønner vi at når jerven samme vinter dreper to dyr fra tamreinselskapet, må den tas av dage. Heine legger ut åte i form av et reinslår som er satt inn med gift og knust glass, slik at jerven skal blø i innvollene og giften gå i blodet. Jerven spiser lårbeinet til reinen, Heine følger i sporet til jerven, som stadig må legge seg ned på grunn av smertene. Han tar den til slutt igjen når de begge er ute på fjordisen. Her blåser det imidlertid opp til storm og Heine blir blåst inn mot steiner i fjæra med slik fart at han omkommer. Jerven derimot overlever.

Et par vintre etter møter vi jerven igjen. To samer følger sporene til jerven inn i ei ur og tetter igjen utgangene slik at den ikke kan komme ut. Synsvinkelen flyttes til jerven der den i desperasjon graver for å komme seg ut, mens den blir stadig mer sulten. Romanen slutter slik: «Selv da tre veker var forbi, hørtes en enkelt gang en svak krafsing inne i ura. Etter denne tida ble det helt stilt» (66). En hjerteskjærende slutt hvis man har levd seg inn i jervens situasjon. Fra reingjeternes side er det derimot en seier, de har lykkes i å drepe et skadedyr.

Fortelleren inntar ingen fordømmende holdning overfor jerv-jegerne, men heller ingen heroisering av jakten. På samme måte er jerven hverken demonisert eller sentimentalt fremstilt. Fønhus peker i fortellingen på konflikten mellom menneske og dyr i dette fjellområdet uten å moralisere. Likevel bidrar han helt klart til å gi et annet bilde av jerv enn det som er vanlig i mange folks forestilling, et blodtørstig rovdyr.

\section{Grågås. - Villgås flyr mot nord (1968)}

I flere av Fønhus’ bøker kan det til tider være vanskelig å avgjøre om det er dyrene eller menneskene som har hovedrollen i den fortellingen vi leser. Det er samtidig nettopp noe av det som er det originale ved bøkene, og noe som Fønhus som den eneste norske forfatter har perfeksjonert. Et vellykket eksempel på denne teknikken med å skifte perspektiv mellom menneske og dyr finner vi i en av hans sene romaner, Villgås flyr mot nord (1968). 
Fortellingen åpner slik: «Gåsetoget fløy over Nord-Afrika. Gjessene kom fra den store floden der, og holdt nå retning mot Middelhavet» (7). Et stort tidsperspektiv trekkes opp av fortelleren: «Egypts dynastier gikk til grunne, og ble erstattet av nye, tusenår hektet seg til tusenår, verden ble en annen - men plogene av store, gråaktige fugler stevnet som før hvert år mot nord» (9). Når gjessene kommer over Sveits, møter vi en eldre mann som er ute og går, Theodor Heuser. Han stanser og ser på gåsetrekket på himmelen over seg. Noen biografi får vi ikke på ham, utover at han halter etter han som ung falt ned i ei ur under jakt på gemser. Vi skal imidlertid møte ham igjen mot slutten av fortellingen, det er han som kommer til å skyte den gåsa vi etter hvert blir kjent med, en gås som er ringmerket i Finnmark.

Når gåsetrekket kommer over Skagerak, skilles to gjess ut for leseren, en hann og en hunnfugl. Vi får høre at de har holdt sammen siden året før og hatt reir i Nord-Norge. Gjessene ankommer Sør-Norge, noe som skildres slik: «Men folk som sto og så etter denne levende plogen, som sang seg fram der høgt oppe, de kjente en liten glede piple i seg nå har vi da endelig våren snart, for nå kommer grågåsa, tenkte de» (11). Gåsetrekket kommer etter hvert til Nord-Norge, til Bardu i Troms, der en liten del av flokken slår seg ned ved Altevann. Igjen blir gjessene observert og skildret av et menneske, en eldre mann som holder til i ei tømmerbu øst ved vannet, i bjørkeskogen: «Jasså, tenkte han, den kom tidlig i vår!» (12). Mannen pleier å jakte gås på høsten, når ungene er vokst til, får vi høre.

De fleste gjessene fortsetter videre nordover, til Finnmarksvidda, og noen igjen lenger øst, til furuskogen på grensen mot Russland og Finland. Her møter vi den norske skogvokteren Embret Tymo som bor på en liten plass i skogen sammen med kone og en sønn på 11 år, Aksel. De setter ut to lokkegjess på en myr og noen av gjessene lander, og de lykkes å skyte en. "Gutten tok den daue gåsa i beina, og lettet den. - Ånei, så stor som ho e’!» (17). Det gåseparet vi har blitt litt kjent med, lander på ei myr i nærheten, der de gjenser reiret fra sommeren før.

Flere av naturbeskrivelsene vitner om inngående naturkunnskap hos forfatteren og er ikke bare impresjonistiske:

Når somt av myrgraset tok til å gro, hadde det en vel tommelang rot under jorda, med skall på. Denne rota likte villgjessene; de lugget den opp, og åt den. Men snart ble det mat nok av flere slag. Sola kom høgere og høgere over synsranda ved midnatt, og fikk sommeren til å piple så fort opp av jorda: duftende finnmarkspors, blid linnea, frodig bregne i de rå sigene, molteblomster som et snøyr over myrene. (18)

Gåseparet vi har blitt kjent med legger denne sommeren fem egg. Et spenningsmoment er det når en rev går forbi, en stor fare for reiret, men reven får ikke været av gåsa. I juli-august, når gjessene feller fjær, kan de ikke fly, og da pleier skoltesamene å jakte gjess, formidler fortelleren, og skildrer en slik jakt der samene ikke bruker skytevåpen, men sniker seg inn mot myrene fra flere kanter og slår gjessene ihjel med lange stenger.

En dag kommer en preparant fra Zoologisk museum i Oslo til Øst-Finnmark. Han tilbyr Embret 50 kroner hvis han klarer å merke en gås. Embret bringer ved et tilfelle en gås med hjem etter den er skadebitt av hunden hans. Gåsa, som får navnet Lasse, bor i en kasse og blir etter hvert ganske tam og følger etter gutten Aksel overalt, og blir til og med venn med hunden. Embret ringmerker fuglen, men den vil ikke fly derfra. 
En dag kommer statens skogforvalter, Broch, med sin hund, og gåsa blir skremt vekk. Aksel finner imidlertid gåsa igjen ved ei myr og bærer den hjem. I første halvdel av september må Aksel igjen begynne på skolen, og gåsa blir latt alene noen dager mens foreldrene følger ham til byen. Gåseparet vi tidligere har blitt kjent med kommer flyvende over skogvokterboligen, får øye på gåsa Lasse og lander. Når de letter igjen for å fly sydover, slår Lasse seg i lag med dem.

Igjen endres perspektivet, vi møter en mann, Bernhard Divihaug, som har feilberegnet matrasjonene på vei gjennom Øst-Finmark. Han er sulten, og når han ser de tre gjessene gående på ei myr og beite, prøver han å fange dem. Dette er Lasse og gåseparet, skjønner leseren. Divihaug har ikke våpen og lykkes ikke, men legger merke til at den ene gåsa ikke virker å være redd for ham. Når han senere forteller dette til skogvokteren Embret, utbryter Embret: «Jasso, va det du Divihaug som skull' kom' med helsing ifra 'n Lasse!» (47).

Enda en hilsen kommer til skogvokterfamilien fra Lasse: Når gåseplogen kommer over gården på vei sydover, bryter ei gås ut av trekket og flyr en ekstra runde over gården før den fortsetter med de andre. Skogvokterfamilien skjønner at det er Lasse som hilser dem.

Ved Altevann i Bardu kommer mannen i tømmerbua ut av huset og ser gåsetoget på himmelen sørover, et tegn på at høsten snart er her. I Nordland skildres gåseplogen av en mann som er ute i vedskogen: «Rett over ham kom gåsetoget, så lågt at han hørte som et sterkt vindsus fra hundrer av vingepar. [...] Han sto der i den gryende dagen og syntes han opplevde noe underlig [...]» (51).

Til slutt, langt utpå høsten, er gjessene tilbake i Afrika. Fortelleren kommenterer det slik: «Gjennom tusener av år var gås kommet der slik. På Egypts mumiekister sto tegnet gåsas bilde» (52).

Fortellingen går over til å skildre vinteren i Finnmark, der vi hører om en kven på bjørnejakt. Så begynner folk i nord å vente på våren.

Om noen veker, når elva var gått opp, ville det bli et fugleliv etter vassdraget som få andre steder i landet. Ender ville snadre, måker trekke innover ute fra havet, det ville komme terner; ternene brukte sitte så tett på tømmerstokkene at hele stokken var som frynset av fugl. Og fiskeørna ville komme seilende på mektige vinger etter elva [...] (56)

Gåseplogen er på nytt på vei fra Afrika. I Alpene i Sveits lander de for å hvile og spise på ei myr. Theodor Heuser er denne dagen ute med børsa og lykkes å skyte ei gås. Han oppdager at den er ringmerket, og leseren skjønner at det er Lasse som er skutt. Heuser sender ringen til Norge, en dag ankommer brevet Øst-Finnmark, og når den lille metallringen faller ut av konvolutten, sier Embret til sønnen, i det som blir slutten på romanen: «Ja, Aksel, her kommer det en helsing til deg fra han Lasse. Og den helsinga fra 'n, det blir nok den siste» (60).

Fortellingen lykkes i å vise den betydning gjessene har for menneskene på flere steder av sin ferd, også i en kulturhistorisk dimensjon. Det uttrykkes en respekt for det naturfenomen gåseplogen er, som en del av årstidenes rytme. Spesielt godt skildret er Aksels forhold til gåsa, han både drømmer om den og har mareritt om at den blir skutt, samtidig som han selv har vært med på gåsejakt. Fortellingen viser hvordan jakt og omsorg for fuglene kan forenes. «Men i skogvokterhuset ved Galgofossen pratet de også ofte om Lasse. De forsto nå at ordtøket om dum som en gås, det var laget av folk som ikke kjente 
denne slags fugler» (54). Personskildringen er knapp, men likevel tilstrekkelig til å skape et givende bilde av menneskeverden og fugleverden, og møtet mellom disse.

\section{Dyrets livsverden}

Timothy Clark skriver i The Cambridge Introduction to Literature and the Environment at: «all human societies define themselves in some basic respects through how they live a human - animal distinction» (Clark 37). Fra 1980-tallet og framover har det vært en stor vekst i det feltet som på engelsk kalles «animal studies», om forholdet mellom menneske og dyr, enten det gjelder dyrs rettigheter, hvordan dyr fremstilles i ulike diskurser (kulturanalyse), studier av husdyr, kjæledyr eller ville dyr.

Fønhus utforsker og formidler i sine bøker hvordan ville dyr i norsk natur sanser og tenker, i tillegg til at han skildrer ladete møter mellom menneske og dyr. Dette gjør etter min mening forfatterskapet interessant og relevant $\mathrm{i}$ forhold til nyere humanistisk dyreforskning.

La oss se på et utdrag fra en av Fønhus' mest kjente bøker, Trollelgen (1921), der det er elgkalvens perspektiv av omverdenen vi får:

Han suger mora. Når mjølka synker varm og rislende fra hennes kropp og inn i hans, da er dette hans første glede i livet. Bevisstheten klarner, som en skyet himmel klarner over ham. Han får sine begreper om tid; lys og mørke, det er tid. Han lærer at dødt vatn tier stille, at levende vatn gir lyd og kan slafse ham om beina med våte og kalde tunger. Og når det blåser, når lufta uroer seg, da kan trærne kvinke og jamre som reveunger.

Han lærer også å kjenne pipet fra hauken og falken, som daler lik store, skjelvende blad oppe under skyene. Om natta gnistrer tall-løse små øyne på himmelen, og det er stjerner. Slike stjerner kan også gnistre fra mørke skogsnar, fra mår og rev, fra alle dyr som reiser seg når sola går ned. (4)

I en skildring som dette viser Fønhus hvordan hendelser adderes og skaper nye reaksjonsmønstre som gjør at man etter hvert kan snakke om en personlighet hos dyret: Dette individet til forskjell fra andre. At flere av dyrene gis personnavn i fortellingene, underbygger det samme. Dyret hos Fønhus handler ikke bare ut fra instinkt, men også fra erfaring. Dyrene blir både representanter for sin art og individuelle vesener med personlighet. Filosofen Lars Svendsen skriver i $\AA$ forstå $d y r$ at: «Jo mer du lærer en art å kjenne, desto mer begynner du å betrakte de enkelte medlemmene av arten som individer» (Svendsen 179). Det er det Fønhus gjør. Anniken Greve skriver i artikkelen «Om dyr og folk» at det i vår kultur er dikterne heller enn filosofene som har utforsket de fellesskapssirklene vi kan slå omkring oss og se våre egne liv i lys av. Filosofene har vært mer opptatt av å trekke opp demarkasjonslinjer, hva er forskjellen på mennesker og dyr. Vi mister da av syne alt vi deler med dyrene, mener Greve:

At vi er kroppslige, sansende, dødelige, fryktsomme, at vi er avhengige av andre av samme art for å overleve som individ, at vi har behov for søvn, mat, at vi er ømfintlige for temperatur og klima og skiftninger i temperatur og klima, osv. (Greve 9) 
Lars Svendsen går enda lenger i å sammenligne mennesker og dyr når han trekker inn bevisstheten: «Filosofer har hatt en tendens til å overvurdere språkets betydning. Etter alt å dømme kan temmelig avansert tankevirksomhet foregå i organismer som ikke har språk i ordets vanlige betydning» (Svendsen 26). Hvordan kan man studere dyrs tanker og følelser? Gjennom adferd, mener Svendsen, for følelser er ikke kun skjulte, rent mentale størrelser, de kommer også til uttrykk gjennom handlinger. Atferd er mettet med mening, som han sier (108). Det kreves både erfaring, kunnskap og sensibilitet for å tolke denne. En slik erfaring, kunnskap og sensibilitet har nettopp Fønhus.

Den tyske skogvokteren Peter Wohlleben skriver i boka Dyrenes indre liv at «hver dyreart ser og opplever verden fullstendig annerledes enn oss, slik at det på sett og vis finnes hundretusenvis av forskjellige verdener» (Wohlleben 214). Vi mennesker reduserer disse verdenene til å snakke om dyrets miljø, men det er sett fra vår synsvinkel. Det dyret selv ser, bør beskrives med et annet begrep. Den tyske filosofen og biologen Jakob von Uexküll foreslår her ordet Umwelt, for å gi perspektivet til dyret. Et spesielt miljø inneholder mange Umwelten, og ingen av dem er like, sier Uexküll. Han tar utgangspunkt i at oppbyggingen av sanseorganene, den sansemengden hvert dyr mottar - og graden av sensitivitet - er forskjellig hos alle dyr, med den følgen at evnen hvert dyr har til å skjelne, er forskjellig fra dyr til dyr. Hvert dyr har sin Umwelt, der det selv er subjekt. Å utforske og forstå et dyrs Umwelt krever stor tålmodighet, fri utveksling av informasjon mellom forskjellige observatører, mange timers direkte observasjon og motvilje mot å generalisere om dyret (Uexküll 53).

Fønhus' dyrefortellinger kan sees som en utforskning av slike Umwelten. I et intervju med Torbjørn Børte sier Fønhus at han i tillegg til observasjon av dyr leser mye dyrepsykologi. Han er særlig opptatt av om reaksjoner hos dyret kan være styrt av refleksjon vel så mye som av instinkt. Likevel advarer Fønhus mot å gå for langt i sin innlevelse med dyrene: «[...] å tillegge dyra menneskelige tanker og følelser - det må en passe seg for. For vi veit ikke akkurat -. Men glede og sorg og trofasthet - det har et dyr like så vel som et menneske» (Børte 113). Dette er i tråd med resultatene fra nyere dyreforskning, noe man f.eks. ser i kapittelfortegnelsen til Peter Wohllebens bok om dyrenes indre liv: «Sorg», «Skamfølelse og anger», «Medfølelse», «Angst», «Altruisme» m.fl. «Hvis dyrene utelukkende hadde vært styrt av et fastlagt genetisk program, ville det ha betydd at alle eksemplarer av en art måtte reagere likt i en gitt situasjon», skriver Wohlleben, og legger til at det erfarer vi at ikke er tilfelle (62). «Hvilken karakter det enkelte dyret utvikler, avhenger av hvilke individuelle genetiske arveanlegg det har, og ikke minst av hvordan det er blitt preget av miljøet, altså av opplevelsene sine» (62).

Fønhus er god til å beskrive nettopp disse opplevelsene dyrene har og hvordan det preger dem. I Trollelgen får vi vite at elgen Rauten liker seg spesielt godt i Rédalen, noe fortelleren formidler i et perspektiv som forsøker å ligge tett på elgens:

Der kan freden i månedsvis ligge og flyte over skogen, det er som freden flyter inn i selve hans egen raggete kropp, han blir sjøl en del av stillheten mellom fjella.

Og ro, det er hans dypeste natur. Han vil se og sjøl være gjemt; han vil stå i myrkantene og se røya smyge med ungeflokken; han vil se skvetten hare sitte i troskyldighet og gnage i faksehallene. Da er det ro; og dagene møter ham med gamle, alltid nye gleder: litt frodig, ennå sommergrønt gras i en myrhals, litt blekkje i en tjennputt. Livet, det er å ete, sove og kvile, å ete igjen. Livet er lys og mørke, sol og regn, varme og kulde. (68) 
Denne roen blir imidlertid i perioder forstyrret av elgjegere. Det er likevel ingen kritikk av elgjakt i boka. Når perspektivet ligger hos jegeren, er vi nærmest tvunget til å følge dette perspektivet. Fortellerteknikken kan kalles perspektivisme. Perspektivisme er noe som blant annet kjennetegner dramaet, siden vi der har ulike personer som snakker uten at det er en overordnet forteller som vurderer og dømmer. Motstridende perspektiver forblir motstridende. Slik er det også i Fønhus sine bøker. Det tas ikke avstand fra jakt. Samtidig skildres dyrets frykt og lidelser. Hos Fønhus tilkjennes mennesket rett til å nyttiggjøre seg av naturen, i likhet med det andre arter gjør. Samtidig gir han oss et ikke-menneskelig perspektiv som vi også må forholde oss til. - Til sammenligning opplever vi aldri dyrets perspektiv i Trygve Gulbranssens roman Og bakom synger skogene (1933), der også jakt på dyr og fugler i de store skogene skildres.

Den jakten Fønhus anerkjenner i sine bøker står i en lokal matauk-tradisjon. Det er ikke sportsjakt eller troféjakt han skildrer, der jegerens maskuline styrke skal bekreftes. Jegeren er hos Fønhus ikke i en overlegen posisjon, men må selv risikere noe, til og med sitt liv, jf. hvordan elgjegeren til slutt dør i Trollelgen, sammen med byttet, og hvordan Heine Juvet mister livet i Jerv, i en forfølgelse av dyret. Dette gjør jakt til noe annet enn nedslakting, noe annet enn dominans, eller det Margaret Atwood kaller «imperialisme».

\section{Avslutning}

Fønhus er kritisk til vekstideologien i den vestlige verden, kravet om stadig større materiell velstand. «Det er en stor villfarelse å tro at enhver forandring er et fremskritt», sier hovedpersonen, Frek, i romanen Veien over fjellet (42). I et foredrag i 1938, med tittelen «Nøysomhet er livskunst», forteller Fønhus om en same han traff på Finnmarksvidda, Store-Aslak:

[Han var] ingen filosof, men han levde likevel som ein filosof, ein vismann, ikkje fordi han hadde reflektert seg til det, men fordi at han heile sitt liv hadde levd i fanget på mor natur, som hadde tvinga honom til det. Og mor natur, ho er den største vismannen tå alle. Men ho ber oss fyst og framst: lev enkelt. (Brandrud 196)

Det å leve enkelt demonstreres i en rekke av Fønhus' bøker, mennesker som lever tett på naturen, i en daglig kontakt med landskap og dyreliv. I Morgenbladet 1961 skriver Fønhus: «Kampen for Natur-Norge er ikke bare naturromantikk. Det er realisme. Det gjelder folkets mentale og fysiske helse» (Brenne 1). For Fønhus er vår agerende og reagerende kroppslige natur noe som er for lite påaktet i det moderne samfunnet. Derfor fortsetter han hele livet å skrive villmarksfortellinger.

Fønhus skriver om det som befinner seg i periferien av vårt fokus, dyrelivet i villmarken. Teknologien har gjort at en direkte kontakt med naturen ikke lenger er nødvendig for oss. Det vi mer og mer forholder oss til er sosiale og kulturelle størrelser. Fønhus' fortjeneste er at også ikke-menneskelig persepsjon utforskes, forstås og anerkjennes. Ikke bare mennesker sanser og føler, det gjør også dyr.

Mikkjel Fønhus sitt bidrag til å diskutere moderniteten er ikke ved å skrive romaner fra byen, industrien eller det moderne liv, derimot ved å skildre så nært og nøyaktig som mulig det som er truet av urbaniteten: villmarken og dyrelivet, og et levesett som er i dag- 
lig kontakt med naturen. Vi deler en sårbarhet med dyrene. Selv om mennesket er alene om å være menneske, er vi ikke alene om å kunne oppleve, like, lide, sulte, avsky, lengte og elske. I det ligger en betydelig mulighet for fellesskap (jf. Svendsen 175). Fønhus' fortellinger viser at selv om mennesker og dyr lever i ulike verdener, er det verdener med flytende grenser. Dyrefortellingene oppøver vår forestillingsevne når det gjelder å forstå dyr. En gjennomgående holdning i forfatterskapet er at menneskelivet er et liv på jorden blant alt levende. Denne enkle innsikten er for Fønhus fundamentalt for vårt moralske liv og engasjement i verden.

\section{BIBLIOGRAFI}

Andersen, Per Thomas. Norsk litteraturhistorie. Oslo: Universitetsforlaget, 2012.

Atwood, Margaret. Survival. A Thematic Guide to Canadian Literature. Toronto: Anansi, 2012.

Beyer, Harald og Edvard Beyer. Norsk litteraturhistorie. Oslo: Aschehoug, 1978.

Brandrud, Rolf. Drømmejegeren. En biografi om Mikkjel Fønhus. Oslo: Aschehoug, 1993.

Brenne, Tom. Mikkjel Fønhus - hans liv og forfatterskap. Oslo: Landbruksforlaget, 1993.

Clark, Timothy. The Cambridge Introduction to Literature and the Environment. Cambridge: Cambridge UP, 2008.

Dahl, Willy. Norges litteratur. Tid og tekst 1884-1935. Oslo: Aschehoug, 1984.

Egeland, Kjølv. Norges litteraturhistorie, bind 5. Oslo: Cappelen, 1975.

Fidjestøl, Bjarne m.fl. Norsk litteratur i tusen år. Oslo: Cappelen, 1996.

Fønhus, Mikkjel. Der villmarka suser. Oslo: Aschehoug, 1976.

Fønhus, Mikkjel. Det skriker fra Kvervilljuvet. Oslo: Aschehoug, 1976.

Fønhus, Mikkjel. Jerv. Oslo: Aschehoug, 1976.

Fønhus, Mikkjel. Snøen fyker over Nøsfjell. Oslo: Aschehoug, 1976.

Fønhus, Mikkjel. Trollelgen. Oslo: Aschehoug, 1976.

Fønhus, Mikkjel. Villgås flyr mot nord. Oslo: Aschehoug, 1976.

Gleditsch, Ulf. Mikkjel Fønhus. Skoggangsmann og tradisjonsboerer. Oslo: Aschehoug, 1960.

Greve, Anniken. «Om dyr og folk». Nordlit 16 (2004): 1-29.

Hauge, Knut. Mikkjel Fønhus. Slik som vi husker ham. Oslo: Aschehoug, 1974.

Houm, Philip. Norsk litteraturhistorie, bind 6. Oslo: Aschehoug, 1955.

Renberg, Tore. Tore Renberg les Mikkjel Fønhus. Oslo: Nasjonalbiblioteket, 2018.

Stensrud, Gudbjørg Fønhus. Mikkjel - far min. Oslo: Aschehoug, 1985.

Svendsen, Lars Fr. H. Å forstå dyr. Filosofi for hunde- og katteelskere. Oslo: Kagge, 2018.

Uexküll, Jakob von. A Foray into the Worlds of Animals and Humans. Oversatt fra tysk av Joseph D. O'Neil. Minneapolis: UP of Minnesota, 2010.

Wohlleben, Peter. Dyrenes indre liv. Kjorlighet, sorg, omtanke. Oversatt fra tysk av Cecilie Horge Walle. Oslo: Cappelen Damm, 2018.

\section{Henning Howlid Worp}

University of Tromsø - The Arctic University of Norway

E-mail: henning.waerp@uit.no 